\title{
Genetic species identification of a Collared Pied Flycatcher from Norway
}

\author{
Timothée Bonnet $\cdot$ Per Kristian Slagsvold • \\ Glenn-Peter Sætre
}

Received: 13 November 2010/Revised: 17 February 2011/ Accepted: 27 April 2011/Published online: 17 May 2011

(C) The Author(s) 2011. This article is published with open access at Springerlink.com

\begin{abstract}
One male Ficedula flycatcher, breeding in southeast Norway, was identified in the field as a putative hybrid between the Pied Flycatcher $F$. hypoleuca and the Collared Flycatcher $F$. albicollis due to the presence of a partial neck collar and other intermediate plumage traits. The male and his seven nestlings were genotyped using species-diagnostic genetic markers, along with three positive controls of both flycatcher species. The male only possessed Pied Flycatcher alleles, suggesting that it is a pure Pied Flycatcher but with rare plumage characteristics approaching those of a Collared Flycatcher. Partial neck collars are also found in other black-and-white flycatcher species; the Semi-collared Flycatcher $F$. semitorquata (regularly) and the Atlas Flycatcher F. speculigera (occasionally), and have also been reported to occasionally occur among the Iberian subspecies of the Pied Flycatcher $(F . h$. iberiae). We suggest that a (partial) neck collar may be the ancestral character state of the common ancestor of these black-and-white flycatcher species, and thus that the trait may also occasionally be expressed in populations that normally lack it. Our study demonstrates that species identification based on morphological cues may sometimes be insufficient, even in species that normally possess species-diagnostic plumage characteristics.
\end{abstract}

Keywords Ficedula hypoleuca - Hybridization . Molecular species identification · DNA barcoding

Communicated by M. Wink.

T. Bonnet · P. K. Slagsvold · G.-P. Sætre $(\bowtie)$

Department of Biology, Centre for Ecological and Evolutionary

Synthesis (CEES), University of Oslo, P.O. Box 1066,

Blindern, 0316 Oslo, Norway

e-mail: g.p.satre@bio.uio.no
Zusammenfassung Ein männlicher Ficedula-Fliegenschnäpper, der in Südostnorwegen brütete, wurde im Freiland als vermeintliche Hybride von Trauerschnäpper $F$. hypoleuca und Halsbandschnäpper $F$. albicollis identifiziert, da er ein unvollständiges Halsband und andere intermediäre Gefiedermerkmale hatte. Das Männchen und seine sieben Nestlinge wurden unter Verwendung artdiagnostischer genetischer Marker genotypisiert, zusammen mit drei Positivkontrollen beider Fliegenschnäpper-Arten. Das Männchen besaß lediglich Trauerschnäpper-Allele, was darauf hindeutet, dass es sich um einen reinen Trauerschnäpper handelte, jedoch mit seltenen Gefiedermerkmalen, die denen eines Halsbandschnäppers ähneln. Unvollständige Halsbänder findet man auch bei anderen schwarzweißen Fliegenschnäpper-Arten, dem Halbringschnäpper $F$. semitorquata (regelmäßig) und dem Atlasschnäpper $F$. speculigera (gelegentlich), und es wurde berichtet, dass sie mitunter bei der iberischen Unterart des Trauerschnäppers $(F . h$. iberiae) auftreten. Wir schlagen vor, dass ein (unvollständiges) Halsband ein ursprüngliches Kennzeichen des gemeinsamen Vorfahren der schwarzweißen Fliegenschnäpper-Arten sein könnte und daher gelegentlich auch in Populationen exprimiert wird, in denen es normalerweise fehlt. Unsere Studie zeigt, dass eine Artbestimmung auf Grund morphologischer Kennzeichen manchmal unzulänglich sein kann, selbst bei Arten, die normalerweise artdiagnostische Gefiedermerkmale besitzen.

\section{Introduction}

Taxon identification is inherently involved in most fields of biology as a central study aim, or at least to guarantee 
Fig. 1 A male Ficedula flycatcher that was thought to possibly be a hybrid between the Pied and Collared Flycatchers due to intermediate plumage characteristics. a Profile: notice the partial neck collar and the relatively large, white forehead patch. b From above: notice the white bands on the primaries, which are relatively broad for a Pied Flycatcher, and the partial neck collar
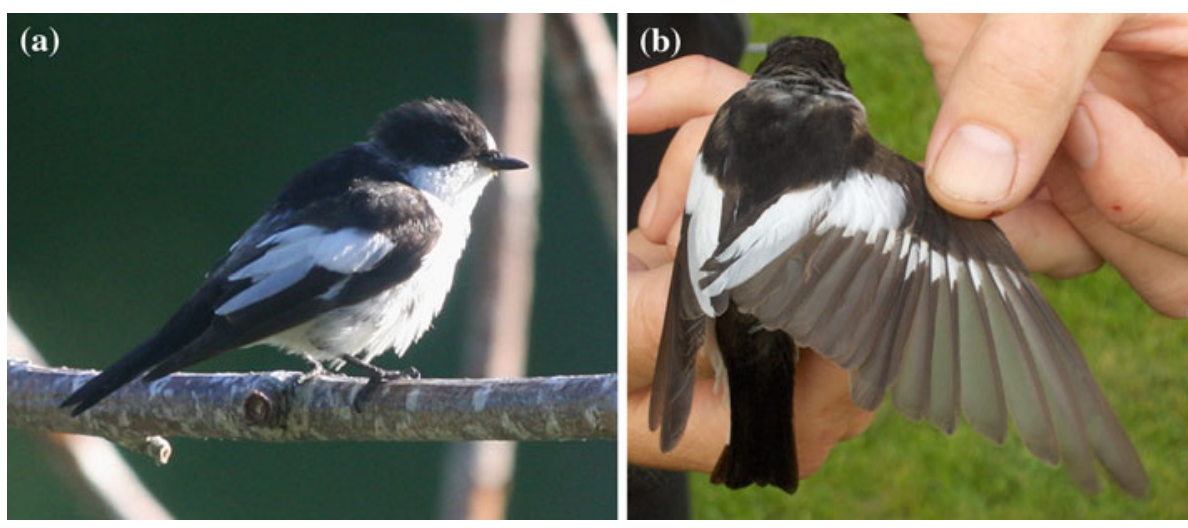

reproducibility. For centuries, morphological cues were the only way to infer identification. Recently, molecular methods have been becoming cheaper, more reliable and faster. Accordingly, tools such as DNA barcoding are becoming standard means to recognize species in many animal taxa (Hebert et al. 2003).

However, both morphological and molecular taxon identification methods can be difficult to use in closely related and/or hybridising taxa. For instance, barcoding is insufficient to identify hybrids because it is based on the maternally inherited mitochondrial genome (an $F_{1}$ hybrid would have the same genotype as its mother). Barcoding may even fail to delimit closely related allopatric species, due to a lack of genetic differentiation at the standard gene in use, the cytochrome oxidase subunit I gene (cox1 or COI) (Aliabadian et al. 2009). To confirm or exclude species or hybrids, specific-diagnostic nuclear genetic markers are needed.

The Pied Flycatcher (Ficedula hypoleuca) and the Collared Flycatcher ( $F$. albicollis) are two small passerine species with a parapatric distribution in Europe. Adult males of the two species differ markedly in breeding plumage characteristics. Male Collared Flycatchers have a species-diagnostic white neck collar, and have also larger white patches on the forehead and on the primaries than a typical Pied Flycatcher (Lundberg and Alatalo 1992). However, juveniles, females and males during the nonbreeding season are much more similar. Moreover, in areas of sympatry on the Swedish isles of Gotland and Öland, and in parts of central and east Europe, the two species hybridize at nontrivial frequencies (e.g., Qvarnström et al. 2010). Male hybrids are intermediate in appearance and typically have a partial neck collar and white patches of intermediate size (Sætre et al. 2003; Svedin et al. 2009).

Here, we investigate the species status of a putative male hybrid found breeding in southeast Norway using speciesdiagnostic genetic markers. Although the Collared Flycatcher is not a regular breeding species in Norway, rare visitors are occasionally observed, including three documented cases of mixed-species breeding with Pied Flycatchers (T. Olsen, Norwegian Rarity Committee, pers. com). It is also possible that hybrids from the Swedish hybrid zone may occasionally stray westwards.

\section{Materials and methods}

\section{Sampling}

The male was captured with a nest box trap in a woodlot about $30 \mathrm{~km}$ northeast of Oslo in June 2010. Blood was collected from the males and his seven chicks using brachial venipuncture, and stored in ethanol. The male displayed several characteristics consistent with being a hybrid, including a partial neck collar and relatively large patches of white on the forehead and primaries (Fig. 1). The plumage color of the back and head of the male was scored according to the 7-point scale of Drost (1936), where score 1 corresponds to completely black upper parts and 7 to completely brown upper parts. We used a 5-point scale to score its partial neck collar $(4=$ complete collar, 3 = gray-hatched collar, $2=$ broken collar, $1=$ semicollar, $0=$ no collar). Finally, for the white band on the primaries, we noted the primary at which the white patch started (counted from the alula and inwards). The Pied and Collared Flycatchers differ in these traits, and hybrids are intermediate (e.g., Sætre et al. 2003).

\section{Morphological analysis}

We compared the phenotype of the focal male with similar, previously published, data from (1) an allopatric Pied Flycatcher population near Oslo, Norway $(n=29)$, (2) a sympatric population at Dlouhá Loučka, Czech Republic ( $n=8$ Pied Flycatchers, $n=32$ Collared Flycatchers, $n=2$ hybrids), and (3) a sympatric population at Löttorp, 
Öland, Sweden ( $n=15$ Pied Flycatchers, $n=45$ Collared Flycatchers, $n=6$ hybrids). The species or hybrid statuses of these birds were confirmed genetically in connection with previous studies (Sætre et al. 2003; Wiley et al. 2009). We used the phenotypic measures of these flycatchers to compute a linear discriminant function that best classified the birds to their respective species class (Pied Flycatcher, Collared Flycatcher, and hybrid), using the "lda" option in $R$. We then used the discriminant function to phenotypically assign the focal male to the Pied, Collared or hybrid class.

Genetic analysis

DNA extractions from blood pellets were performed using a Genemole isolation robot (Mole Genetics) by applying a standard blood extraction program, after an incubation in $175 \mu \mathrm{L}$ Queens lysis buffer and $25 \mu \mathrm{L}$ proteinase $\mathrm{K}$ solution $(10 \mathrm{mg} / \mathrm{mL})$ at $56^{\circ} \mathrm{C}$ during $1 \mathrm{~h}$ $30 \mathrm{~min}$. In addition, as positive controls, we included DNA from three Collared Flycatchers from Brečlav, Czech Republic, and three Pied Flycatchers from Dlouhá Loučka, Czech Republic, isolated in a previous study (Sætre et al. 2003).

We amplified a fragment of the control region (CR) of the mitochondrial genome using the primers (L CSB): $5^{\prime}$-TGA ATG CTT GCC GGA CAT GCT TAC- $3^{\prime}$ and (H Phe): 5'-GCA TCC GTC TTG GCA TCT TCA GT- $3^{\prime}$ (Sætre and Moum 2000). The fragment harbors a speciesdiagnostic insertion-deletion (indel), in which Collared Flycatchers possess a fragment of 401 base pairs (bp) and Pied Flycatchers 369 bp (Sætre and Moum 2000). The fragments were length separated using electrophoresis on a $2 \%$ agarose gel. The gel was fixed in an ethidium bromide bath, washed in water, and the relative fragment lengths were investigated in UV light.

Further, we amplified the first intron of the nuclear rhodopsin gene (Rho-1) using the primers F: 5'-CAT CGA GGG CTT CTT TGC C- $3^{\prime}$ and R: $5^{\prime}$-TTT AGA CAC ACA ATT TCT ATT TAA CAC CTGT-3' (Borge et al. 2005). The fragment harbors one species-diagnostic nucleotide site (the two species are fixed for different nucleotides), as well as two nucleotide sites where the Pied Flycatcher is monomorphic and the Collared Flycatcher polymorphic (Borge et al. 2005).

For both markers, PCR amplification was performed in $40 \mu \mathrm{L}$ reactions containing $8 \mu \mathrm{L}$ of template DNA ( $\approx 15 \mathrm{ng} / \mu \mathrm{L}$ concentration), $0.8 \mathrm{U}$ Hot Start polymerase (Phusion), $200 \mu \mathrm{M}$ dNTPs, $8 \mu \mathrm{L}$ HF buffer (Phusion), $1.2 \mu \mathrm{L} 100 \%$ DMSO, and 20 pmol of each primer. All PCRs were carried out on a PTC-240 DNA engine Tetrad 2 cycler (MJ Research, Waterton, MA, USA) using 40 cycles of amplification with $98^{\circ} \mathrm{C}$ for $8 \mathrm{~s}, 59^{\circ} \mathrm{C}$ for $30 \mathrm{~s}$ and $72^{\circ} \mathrm{C}$ for $30 \mathrm{~s}$, preceded by $30 \mathrm{~s}$ of pre-denaturation at $98^{\circ} \mathrm{C}$ and followed by a $7-\mathrm{min}$ extension step at $72^{\circ} \mathrm{C}$.

ExoSAP-IT (USB Corporation, Cleveland, OH, USA) was used to clean the Rho- 1 sequences. We followed the manufacturer's recommendations except for the amount of ExoSAP-IT used per $\mu \mathrm{L}$ of PCR product (ExoSAP-IT was diluted 10 times) and the incubation time for degrading primers and nucleotides $\left(37^{\circ} \mathrm{C}\right.$ for $45 \mathrm{~min}$ instead of 15 min). We sequenced the Rho-1 fragment on an ABI 3730 high-throughput capillary electrophoresis instrument using the same primers as in the PCR. Sequences were edited by eye and aligned using Sequencher v.4.8 (Gene Codes Corp., Ann Arbor, MI, USA).

\section{Results and discussion}

Plumage characteristics of the putative hybrid and comparisons with Pied Flycatchers, Collared Flycatchers and $F_{1}$ hybrids are presented in Table 1 . The focal bird closely resembles a true hybrid. Indeed, the linear discriminant function analysis computed on the basis on the three measures shown in Table 2 assigned the focal bird to the hybrid class.

The genetic results are summarized in Table 2. The putative hybrid male and its nestlings displayed a short, Pied Flycatcher specific mitochondrial CR fragment that was identical to that in the three Pied Flycatcher controls. Moreover, they were homozygous for the Pied Flycatcher version of the species-diagnostic nucleotide site of Rho-1 (position 315), and also monomorphic at the two other sites where only Collared Flycatchers are polymorphic (positions 46 and 326).

Table 1 Phenotypic measures of the focal bird (putative hybrid) in comparison with previously published measures of Pied Flycatchers, Collared Flycatchers, and their hybrids; mean (standard deviation) values are shown

\begin{tabular}{llll}
\hline & Color score & Wing patch & Neck collar score \\
\hline Putative hybrid $(n=1)$ & 2 & 4 & 2 \\
Pied Flycatchers $(n=52)$ & $3.71(1.48)$ & $6.19(0.49)$ & $0(0)$ \\
Collared Flycatchers $(n=77)$ & $1.20(0.39)$ & $3.48(0.87)$ & $3.84(0.37)$ \\
$F_{1}$ hybrids $(n=8)$ & $2.54(1.00)$ & $4.58(1.18)$ & $1.89(0.35)$ \\
\hline
\end{tabular}


Table 2 Genotypes at the mitochondrial DNA marker CR and the nuclear marker Rho- 1 of a putative hybrid flycatcher male and its seven nestlings

\begin{tabular}{|c|c|c|c|c|}
\hline \multirow[t]{2}{*}{ Individual } & \multirow[t]{2}{*}{ CR fragment length (bp) } & \multicolumn{3}{|l|}{ Rho-1 } \\
\hline & & Pos. 315 & Pos. 326 & Pos. 45 \\
\hline F. albicollis (1st control) & 401 & $\mathrm{G} / \mathrm{G}$ & $\mathrm{G} / \mathrm{A}$ & $\mathrm{T} / \mathrm{T}$ \\
\hline F. albicollis (2nd control) & 401 & $\mathrm{G} / \mathrm{G}$ & $\mathrm{G} / \mathrm{G}$ & $\mathrm{T} / \mathrm{G}$ \\
\hline F. albicollis (3rd control) & 401 & $\mathrm{G} / \mathrm{G}$ & $\mathrm{G} / \mathrm{G}$ & $\mathrm{T} / \mathrm{G}$ \\
\hline F. hypoleuca (all 3 controls) & 369 & $\mathrm{~A} / \mathrm{A}$ & $\mathrm{A} / \mathrm{A}$ & $\mathrm{G} / \mathrm{G}$ \\
\hline Putative hybrid male & 369 & $\mathrm{~A} / \mathrm{A}$ & $\mathrm{A} / \mathrm{A}$ & $\mathrm{G} / \mathrm{G}$ \\
\hline Nestlings 1-7 & 369 & $\mathrm{~A} / \mathrm{A}$ & $\mathrm{A} / \mathrm{A}$ & $\mathrm{G} / \mathrm{G}$ \\
\hline
\end{tabular}

Genotypes of previously identified Collared and Pied Flycatchers (three of each species) are shown for comparison

The genotypes of the putative hybrid and its nestlings are thus consistent with them being pure Pied Flycatchers, and we can rule out the possibility that the male is a Collared Flycatcher or an $F_{1}$ hybrid. We cannot rule out the idea that the male is derived from a hybrid due to backcrossing with a Pied Flycatcher, but we consider this possibility unlikely. This is because hybrids between the two flycatcher species have extremely low fitness (Wiley et al. 2009). Accordingly, even at the centers of the hybrid zones, the frequency of backcrosses is vanishingly small. The vast majority of birds of mixed origin are $F_{1}$ hybrids, which again are greatly outnumbered by genetically pure Collared and Pied Flycatchers (Qvarnström et al. 2010; Sætre and Sæther 2010). For instance, only one out of the 219 flycatchers breeding in the studied nest box areas of Öland in 2004 was a backcross (Wiley et al. 2009), and no backcross has so far been identified outside the hybrid zones. We thus consider it much more likely that this odd-looking male is a pure Pied Flycatcher, but one with rare plumage characteristics resembling those of a hybrid.

The Pied and the Collared Flycatchers are part of a species complex that also includes the Semi-collared Flycatcher ( $F$. semitorquata) and the Atlas Flycatcher (F. speculigera) (Sætre and Sæther 2010). Plumage traits, including neck collars and the size of the white patches on the forehead and the primaries, exhibit variation both across the four species and between populations of the same species. For instance, a partial neck collar is a regular trait among male Semi-collared Flycatchers (but some have no collar), an occasional trait among Italian Collared Flycatchers (but most have a complete collar), and an occasional trait among Atlas Flycatchers and the Iberian subspecies of the Pied Flycatcher $F$. h. iberiae too (in both of these latter cases, the majority of the males have no collars) (Potti and Merino 1995; Sætre et al. 2001, 2003; GPS personal observations). In short, a partial neck collar can be found in any of the four species, but at different relative frequencies in different populations. We suggest that a partial neck collar may be the ancestral character state in the common ancestor of the four species. Hence, the trait may also occasionally be expressed in populations that normally lack it.

Our study demonstrates that species identification based on morphological cues may sometimes be insufficient, even in species that normally possess species-diagnostic plumage characteristics. We recommend the use of speciesdiagnostic nuclear markers along with mtDNA markers for the species identification of closely related species that may sometimes hybridize.

Acknowledgments We thank T. O. Elgvin, A. Fijarczyk and N. W. Steen for help in the lab, and P. Gylseth and C. Lome for help in the field. Financial support was received from CEES, University of Oslo.

Open Access This article is distributed under the terms of the Creative Commons Attribution Noncommercial License which permits any noncommercial use, distribution, and reproduction in any medium, provided the original author(s) and source are credited.

\section{References}

Aliabadian M, Kaboli M, Nijman V, Vences V (2009) Molecular identification of birds: performance of distance-based DNA barcoding in three genes to delimit parapatric species. PloS ONE 4:e4119. doi:10.1371/journal.pone.0004119

Borge T, Webster MT, Anderson G, Sætre GP (2005) Contrasting patterns of polymorphism and divergence on the $\mathrm{Z}$ chromosome and autosomes in two Ficedula flycatcher species. Genetics 171:1861-1873. doi:10.1534/genetics.105.045120

Drost R (1936) Über das Brutkleid männlicher Trauerfliegenfänger, Muscicapa hypoleuca. Vogelzug 6:179-186

Hebert PDN, Cywinska A, Ball SL, DeWaard JR (2003) Biological identifications through DNA barcodes. Proc R Soc London B 270:313-321. doi:10.1098/rspb.2002.2218

Lundberg A, Alatalo RV (1992) The pied flycatcher. T\&AD Poyser, London

Potti J, Merino S (1995) Some male pied flycatchers Ficedula hypoleuca in Iberia become collared with age. Ibis 137:405-409

Qvarnström A, Rice AM, Ellegren H (2010) Speciation in Ficedula flycatchers. Phil Trans R Soc Lond B 365:1841-1852. doi: 10.1098/rstb.2009.0306 
Sætre GP, Moum T (2000) A simple molecular method for species identification of pied and collared flycatchers. Hereditas 132:171-172

Sætre G-P, Sæther SA (2010) Ecology and genetics of speciation in Ficedula flycatchers. Mol Ecol 19:1091-1106. doi:10.1111/j. 1365-294X.2010.04568.x

Sætre GP, Borge T, Moum T (2001) A new bird species? The taxonomic status of "the Atlas flycatcher" assessed from DNA sequence analysis. Ibis 143:494-497

Sætre GP, Borge T, Lindroos K, Haavie J, Sheldon BC, Primmer C, Syvänen AC (2003) Sex chromosome evolution and speciation in Ficedula flycatchers. Proc R Soc Lond B 270:53-59. doi: 10.1098/rspb.2002.2204

Svedin N, Wiley C, Veen T, Gustafsson L, Qvarnstrom A (2009) Natural and sexual selection against hybrid flycatchers. Proc R Soc Lond B 275:735-744. doi:10.1098/rspb.2007.0967

Wiley C, Qvarnstrom A, Andersson G, Borge T, Sætre GP (2009) Postzygotic isolation over multiple generations of hybrid descendent in a natural hybrid zone: how well do singlegeneration estimates reflect reproductive isolation? Evolution 63:1731-1739. doi:10.1111/j.1558-5646.2009.00674.x 